\title{
Madrasah Head Policy in Improving the Quality of Teacher Profession
}

\author{
Aswatun Hasanah ${ }^{1, a^{*}}$, Ipon Nonitasari ${ }^{1, b}$, and Hasna Habibah ${ }^{1, c}$ \\ ${ }^{1}$ Islamic Elementary School Teaching, Tarbiyah Faculty, Sunan Kalijaga Stase Islamic University, Yogyakarta, \\ 55281, Indonesia \\ a aswatunhasanah23@gmail.com; b iponnonitasari21@gmail.com; c hasnahabibah1996@gmail.com \\ Corresponding Author : aswatunhasanah23@gmail.com
}

\begin{abstract}
This study examines the policies of Islamic elementary school heads in improving the quality of the profession of Islamic elementary school teacher. The focus of the discussion on this research is how the teacher's profession is, how to improve the quality of the teacher profession, how to evaluate in improving the quality of the teacher profession. This research uses a qualitative approach with field study methods. The results of this study show that the policy of the head of Islamic elementary school in improving the quality of the teacher profession in MI Ma'arif Saman Bangunharjo Sewon Bantul Yogyakarta as follows: 1) Make himself (Islamic elementary school head) as an example. 2) Include Training, Training or Workshop. 3) Activate Teachers In Professional Organizations. 4) Conduct Class Action Research (PTK). 5) Supports improving teacher qualifications. 6) Follow The Latest News. And In order to conduct supervision to improve the professional competence of teachers, there are several things that need to be done by the head including 1) Making a visit to the classroom. 2) Monitor extracurricular activities. 3) Conduct administrative examination of Teaching Learning Activities (KBM). 4) Give a direct reprimand. The supporting factor in improving the quality of the teacher profession is the first of the seriousness of the madrassah head to the main capital as well as his commitment to improving the quality of Islamic elementary school. Both enthusiasm teachers to make improvements from the problems that arise in order to improve the quality of their profession. While the inhibitory factor in improving the quality of the teacher profession is the availability of infrastructure facilities that are still minimal.
\end{abstract}

Keywords: Policy; Quality; Teacher Profession;

\section{Introduction}

Indicators of the progress of a nation can be seen from the education system imposed. In Indonesia the education system applied is still the same just always get polished according to the government's wishes every time the change of minister, it makes the quality of our education up and down erratic. To realize quality education, teachers are one of the machines in succeeding the implementation of national education. Teachers are becoming a link that connects teaching with the hope of a better education future. And being a teacher is a profession full of challenges that face the demands of the quality of the profession, the trust of the parents, the community, the government (Irwandi, 2015).

Speaking of professions, in the Great Dictionary of Bahasa Indonesia (KBBI) is defined as a field of work based on a particular skill education (Pusat Bahasa, 2001). Leiberman said in his book Education A Profession that the profession is the main pressure lies in devotion that should be carried out rather than on its benefits or the devotion entrusted fully by the community (Feisol, 1995). A professional is a job or activity performed by a person and becomes a source of life income that requires skills, skills, or proficiency that meet certain quality standards or norms and require a professional education.

This is in accordance with Law No.14 of 2005 on Teachers and Lecturers article 1 paragraph 1 mentions that professional educator teachers who have a duty to educate, teach, guide, direct, train, assess, and evaluate students both in early childhood educators formal pathways, primary education, and secondary education. So it is understandable that the teacher profession is a job with its obligation to teach, educate, guide, direct, train, assess, and evaluate that has been entrusted by the community based on a particular skill education. 
Basically the teacher is a professional position, which will be effective if the teacher has a certain degree of professionalism by reflecting from competencies, skills, proficiency, or skills that meet quality standards or ethical norms to support his duties. As stated in the Regulation of the Minister of National Education No.16 of 2007 mentions the four basic competencies of a teacher namely pedagogical komptensi, personality competency, social competence, and professional competency that become the demands of a teacher in the middle of the development of the times (Permendikbud, 2007).

The point of view above the tastes is not easy to become a teacher today, because teachers become the focal point of criticisms of education problems in Indonesia. However, the source of education problems in Indonesia itself is not only a matter of teachers, but more a matter of government and community attention, education funding, curriculum, methodology, majamen, school leaders who have professional skills and integrity in managing education.

School leaders are at the forefront of coordinating to improve quality learning and are responsible for achieving educational goals at the highest levels in their respective schools. The achievability of the mission vision and educational objectives in the school depends on the proficiency and wisdom of the school leader in organizing and organizing and collaborating with teachers in educating their students (Yuliana, 2015). With the professionalism of the school leader or the head of the madrassah, the improvement of the quality of the teacher profession can be done because according to its function, the principal understands the needs of his school led so that the competence of the teacher is not the way in place in the teacher's compound that has previously been, but rather can increase and develop well so that the professionalism of the teacher will be realized.

Therefore, any improvement efforts made in order to improve the quality of education will not make a significant contribution without the support of professional and qualified teachers or in other words, improvements in the quality of education should be based on teachers and lead to teachers as well (Mulyasa, 2008).

As for this paper, the author will discuss about teacher professionalism, how the Islamic elementary shcool head policy improves the quality of the teacher profession, how supervision in improving the quality of the teacher profession and supporting factors and inhibition of improving the quality of the teacher profession. The results and discussions described in this paper are expected to be useful information. In addition, this paper is also expected to be a supporting study for the relevant next writings.

\section{Materials and Methods}

This research uses a qualitative approach with field study methods. A qualitative approach is a study that intends to understand phenomena about what research subjects experience such as behavior, perception, motivation, etc. holistically (intact) and by way of description in the form of words and language in a special context experienced by utilizing various scientific methods (Meleong, 2005).

The object of the study in this study was madrassah head and ibtidaiyah madrassah teacher Ma'arif Saman. Data collection methods are a way for researchers to collect research data in research respondents (Sitorus, 2011). To obtain data and information in this study, the data collection techniques in this study use interviews and documentation (Aswita, 2018).

\section{a. Interview Method}

Interviews of informants as data sources and informants are conducted with the aim of extracting information about the focus of research. According to Bogdan and Biklen the interview is a purposeful conversation, usually between two people ( but sometimes more) directed by one with the intention of obtaining information. In other words interviews are conducted to connect about people, events, activities, organizations, feelings, motivations, demands of care and others (Salim, 2009).

This method the author uses to obtain information from principals and teachers related to the Teacher's Professional Development Policy in the school, through questions that have been prepared in advance carefully and in accordance with the purpose of research.

\section{b. Documentation Method}

The document is a record of events that have passed. Documents can take the form of writings, drawings, or monumental works of a person. Documents in the form of writing such as stories, biographies, rules, policies. Documents in the form of drawings such as photos, live drawings, sketches and others (Sugiyono, 2016). 


\section{Results And Discussions}

Based on the results of the research conducted in MI Ma'arif Saman Bangunharjo Sewon Bantul, it can be described several things related to the policy of the head of madrassah in improving the professionalism of teachers, namely as the head of madrassah who has more flying hours than other teachers so that all the experiences he has applied to the implementation of learning in MI Ma'arif Saman Bangunharjo Sewon Bantul. In addition, the support of both the madrassah and outside masdrasah such as the surrounding community environment became a strong encouragement of the madrasah chief to bring MI Ma'arif Saman Bangunharjo Sewon Bantul to success. As well as thempakmpakkan between teachers, supervisors, madrassah committees that run well so as to get policies with consensus deliberations.

\subsection{Teacher Professionalism}

According to Hasan in Abdul Hadith stated as a professional the teacher must meet the following criteria:

1. Have commitment to students and their learning process.

2. Mastering the subject matter to be given as well as the srategi and the way of teaching given to students.

3. Have a responsibility to monitor the learning results of students with various evaluations applied.

4. Can think systematically from what he does and can learn from his professional environment.

Teachers not only deliver materials to students, but do education and guidance. Therefore, teachers must have the ability to motivate learning, understand the talents, interests and potential of students so that teachers can provide services and facilitate the needs of students to the maximum.

As one of the components that determine the success of learning towards a quality education. Teachers should have skills and behaviors that can influence students fully in developing their potential by mastering basic teacher competencies.

The Ministry of Education and National Culture assigns ten must-have skills as a professional teacher, including a) teaching planning ability, b) ability to manage the learning process of teaching, c) ability to manage classes, d) ability to master the foundations of education, e) ability to manage the intraction of teaching learning, f) ability to assess the learning performance of students, g) ability to provide guidance services, h) ability to administer classes and schools i) the ability to understand and interpret research results for teaching purposes (Departemen Pendidikan Nasional, 2006).

The professional competence of Madrasah Ibtidaiyah teachers is a competency that must be possessed by teachers at the elementary/mi level to their ability to carry out duties as a teacher in the school by referring to the Regulation of the Minister of National Education No.16 of 2007 on Academic Qualification Standards and Teacher Competency which explains that professional competencies are: 1) mastering the material, the structure, concepts, and mindset of the science that supports the subjects he has, 2) master the basic competencies and competencies of the subjects/areas of development that arempu, 3) develop creativelympu learning materials, 4) develop the profession on an ongoing basis by taking reflective actions, 5) utilizing information and communication technology to communicate and develop themselves (Permendikbud, 2007).

While social competence is the ability of teachers to communicate and interact effectively and efficiently with students, co-workers, parents of parents of students, and surrounding communities. Communication is built both verbally, write or gesture politely and teachers should be able to use communication technology and information functionally according to the development of the times. Interact or get along politely with the surrounding community who heed the prevailing norms and rules and value systems and apply the principles of persaudaran and semanagt togetherness.

Of the four teacher competencies, a teacher has bagged three of the requirements of a professional teacher including 1) academic qualification s-1 or D-IV, 2) has four teacher competencies, and 3) has an educator certificate. So that a teacher can enroll in teacher certification registration in accordance with the policy stated in the State Direction Outline (GBHN 1999-2004) and strengthened by Law No.20 of 2003 on the national education system, namely related to the certification policy of teachers and lecturers.

It is also expected that the certification policy can boost the quality of quality education of teachers and lecturers as professionals with the goal of teachers and lecturers getting welfare above the word worthy.

From the results of interviews with madrassah heads and teachers at MI Ma'arif Saman Bangunharjo Sewon Bantul Yogyakarta for teacher certification from all 9 teachers already certified 6 teachers, this indicates that the teachers in MI Ma'arif Saman are enthusiastic and have full awareness that there needs to be a competency improvement in the teacher periodically. This indicates that the human resources in MI Ma'arif Saman are willing to follow developments and improve their quality.

Not only professional competencies must be possessed by the teacher profession, but there are other 
competencies such as pedagogical competencies, personality competencies, and social competencies that must also be mastered by teachers. Pedagodic competencies include the understanding of students, the design and implementation of learning evaluation of students' learning outcomes, and the development of students to realize their talents and potential.

Personality competency is a competency related to the personality of a teacher itself such as behavior, the actions of the teacher. In this competency the teacher must be able to direct himself to be a teacher who is atut to be exemplified by the learner, because in fact the teacher (gugu and imitated) means to be trusted and imitated where the teacher is a public figure for his students.

In addition, teachers in MI Ma'arif Saman Bangunharjo Sewon Bantul can also be classified as professional teachers. Because the results of interviews with teachers and madrassah heads in MI show good two-way communication between teachers and other relevant parties, the readiness made by teachers before carrying out the learning process in the classroom is shown with the media used in learning, planting critical attitudes and daring not to follow less educational behaviors can be seen when the teacher conducts the development and elaboration of the subject matter itself in the curriculum, and teachers focus on empowerment and conditioning by paying attention to the conditions of the students who will be educated and mentored.

\subsection{Madrasah Head Policy in Improving The Quality of Teacher Professionalism}

As head of Islamic Elementary shcool has responsibility for all madrassah management activities. Therefore, Nur Hidayat's father included his qualified teachers in his field to perform mandated tasks such as curriculum, student, administration, and others. Related to the increasing professionalism of teachers can be carried out and developed by madrassahs, especially madrassah heads who have full authority. The policy of madrassah heads in improving the professionalism of teachers in MI Ma'arif Saman Bangunharjo Sewon Bantul Yogyakarta is as follows:

1) Make himself (head of madrassah) as an example

As an example that can be applied by the head of madrassah one example is to come early, solve problems with deliberation, and follow madrassah activities directly.

2) Include Training, Training or Workshop

Training, training, or workshop as a place to gain new experience, skills, and knowledge about various problems of implementing teacher duties both related to the assignment of subject matter, mastery of methods, obstacles faced during learning including its countermeasures and problems related to the evaluation and assessment of students' learning outcomes.

3) Activate Teachers in Professional Organizations.

Madrasah heads can activate teachers in various activities such as participating in the Teacher Working Group (KKG), a cluster that is a place to bring teachers together in developing their professional competencies. So as to build a professional attitude according to the field of materials as well as as a training event and a place to change your mind and as a place to solve various problems related to the teacher profession. On the other hand, the teacher working group (KKG) can also improve the quality of teachers and improve the quality of education itself as well as improve the quality of learning achievement and the output of schools is increasingly quality.

4) Conducting Class Action Research (PTK)

Class Action Research conducts reflective research conducted by teachers in order to improve their professional competencies. Class Action Research (PTK) has the goal of 1) improving and improving the condition and quality of learning in the classroom, 2) improving professional services to students in classroom learning, 3) giving teachers the opportunity to take action in planned learning in the classroom, and 4) giving teachers the opportunity to conduct assessment of learning activities. And the benefits obtained include 1) to develop and innovate learning, 2) as an effort to develop curriculum/methods in learning in the classroom, 3) as an improvement of teacher professionalism through research conducted.

5) Supports improved teacher qualifications

As the head of madrassah should be able to provide support to his teachers, one of which is to give permission for teachers to continue higher education levels in order to raise the teacher education qualifications. It must be supported so that not only the teachers can experience and good quality but for madrasahpun will have a positive impact that the quality of madrasah is getting better because the human resources (teachers) are better. In MI Ma'arif Saman Bangunharjo Sewon Bantul for the qualification of teachers from all existing teachers namely 9 people have diplomas S-1 and 3 people have qualified S-2, that means the more madrasah heads give permission to continue their education for teachers the more teachers qualified S-2 or even up to the level of S-3. 
6) Follow The Latest News

In addition to reading scientific works, reading educational books, teachers are also required to follow the actual news as support in improving their professionalism. By following the latest news and information, teachers can keep up with the development of education and can be made into new innovations that are better in accordance with the demands of education and the development of the times.

\subsection{Supervision of Madrassah Head in Improving The Quality of Teacher Professionalism}

In his role as a supervisor to improve the professional competence of teachers, there are several things that need to be done by madrassah heads including (Sari, 2015):

1. Making a visit to the classroom, this visit is done by informing the teacher in advance that there is preparation, but sometimes it is also necessary without notice so that teachers and students do activities in the original class as it is in accordance with their daily learning process in class. From the results of the class visit, the head of the madrassah can discuss with the teacher the problems found during the visit and are both looking for a way out so that it can be applied for even better learning.

2. Monitor extracurricular activities. After the class visit is done by the head of madrassah, another thing is to monitor extracurricular activities as a step to record the talents and potential of students who can then be developed both in the classroom and outside the classroom according to the potential of each learner.

3. Conduct administrative examination of Teaching Learning Activities (KBM). This administrative examination is carried out by the head of madrassah by looking at and analyzing from the Learning Implementation Plan (RPP), syllabus, semester program, knowanan program and others so that it can be known already the way or not between what is planned and what is done.

4. Give a direct reprimand.

The reprimand given by the head of the madrassah is nothing but a goal so that the teacher does not protract in making mistakes so fatal later. Because if mistakes are made continuously until ingrained it will be very difficult to change or correct. Therefore, a direct rebuke from the head of the madrassah serves to prevent greater confusion, as well as maintain the privacy of teachers so as not to feel ashamed if reprimanded in front of the public.

From the results of the supervision carried out by the head of madrassah there needs to be follow-up so that the problems can be solved and have a real impact in the professional improvement of teachers. The follow-up can be strengthening and rewarding, educating reprimands, and providing opportunities to participate in training, stewarding, further workshops. Thus, the supervision and assessment of the head of the madrassah can reduce the constraints that arise and also give the teacher the opportunity to improve his performance and the quality of learning for the development of the madrassah.

\subsection{Supporting Factors and Inhibition in Improving The Quality of Teacher Professionalism}

In the process of implementing the policy of madrassah heads in improving the quality of the teacher profession there are certainly supportive factors and there are factors that hinder. Similarly, in MI Ma'arif Saman Bangunharjo Sewon Bantul Yogyakarta from interviews with madrassah heads and teachers, the supporting factor in improving the quality of the teacher profession is the first of the seriousness of the madrassah head as the main capital as well as its commitment to improve the quality of madrassahs so that the most encouragement is on teachers to always improve things that are still not good. Because the head of the madrassah has full authority over the success of the madrassah so much that it needs its participation. Both teachers' enthusiasm to make improvements from the problems that arise in order to improve the quality of their profession so that when the head of madrassah has the seriousness to improve the quality of madrassahs through improving the quality of teachers then greeted with enthusiasm already the quality of madrasah is not in doubt. Because with the communication and thempakkan between the teacher and the head of the madrassah makes the madrassah significant progress.

The hindering factor is the challenge that must be faced together, the challenge can come from within the maupuun outside the madrassah. In order to improve the quality of the teacher profession based on the results of interviews that are a factor of inhibition from within madarasah is the lack of availability of infrastructure facilities one example madarasah land in MI Ma'arif Saman that does not meet enough standards so that it becomes an obstacle because it has not maximally supported the improvement of the quality of the teacher profession. 


\section{Conclusion}

Based on the results and discussions outlined, there are two conclusions in this writing, namely the policy of the head of madrassah in improving the quality of the teacher profession in MI Ma'arif Saman Bangunharjo Sewon Bantul Yogyakarta as follows: 1) Make himself (head of madrasah) as an example. 2) Include Training, Training or Workshop. 3) Activate Teachers In Professional Organizations. 4) Conduct Class Action Research (PTK). 5) Supports improving teacher qualifications. 6) Follow The Latest News.

And In order to conduct supervision to improve the professional competence of teachers, there are several things that need to be done by the head including 1) Making a visit to the classroom. 2) Monitor extracurricular activities. 3) Conduct administrative examination of Teaching Learning Activities (KBM). 4) Give a direct reprimand. The supporting factor in improving the quality of the teacher profession is the first of the seriousness of the madrassah head to the main capital as well as his commitment to improving the quality of madrassahs. Both enthusiasm teachers to make improvements from the problems that arise in order to improve the quality of their profession. While the inhibitory factor in improving the quality of the teacher profession is the availability of infrastructure facilities that are still minimal.

\section{References}

Barret, Angeline, Sajid Ali, John Clegg etc. (2007). Initiatives to improve the quality of teaching and learning. Eduqal: A Research Programme Consortium on Implementing Education Quality in Lo Income Countries.

Danim, Sudarman. (2013). Profesionalisasi dan Etika Profesi Guru. Bandung: Alfabeta.

Irwandi. (2015). Profesionalisme dan Sertifikasi Guru Di Era Reformasi Pendidikan. Manajer Pendidikan, Vol. 9 No. 4

Lampiran Peraturan Menteri Pendidikan Nasional No.16 Tahun 2007 Tentang Standar Kualifikasi Akademik dan Kompetensi Guru

Lampiran Undang-Undang No.14 Tahun 2005 Tentang Guru dan Dosen

Meleong, Lexy J. (2005). Metodologi Penelitian Kualitatif. Bandung: Remaja Rosdakarya.

Mujtahid. (2009). Pengembangan Profesi Guru. Malang: UIN Malang Press.

Mukhtar, Kasful Anwar \& Emmi Kholilah Harahap. (2019). Benchmarking Head Of Madrasah Doing Madrasah Transformation In Jambi Province. International Journal of Research Granthaalayah.

Mulyasa. (2007). Standar Kompetensi dan Sertifikasi Guru. Bandung: Remaja Rosdakarya.

Pusat Bahasa Departemen Pendidikan Nasional. 2001, Edisis III. Kamus Besar Bahasa Indonesia. Jakarta: Balai Pustaka.

Rifai, Muhammad. (2011). Sejarah Pendidikan Nasional dari Masa Klasik Hingga Modern. Jogjakarta: Ar-Ruz Media.

Risnita, Ruliwati, \& Ifa Pohan. (2019). Performance Evaluation of the Head Master of Madrasah Tsanawiyah State Jambi City. Advances in Social Science, Education and Humaniora Research, vol.438. Atlantis Press.

Sari, Yulia Purnama. (2015). Kepemimpinan Kepala Sekolah dalam Meningkatkan Kompetensi Profesional Guru Di SMA. Manajer Pendidikan, Vol.9 No.4.

Sitorus, Masganti. (2011). Metode Penelitian Pendidikan Islam, Medan: IAIN PERS.

Sugiyono. (2016). Metode Penelitian kuantitatif, Kualitatif dan RED. Bandung: Alfabeta.

Wahyudi, Sugiharto, Masrukhi, \& Ahmad Rifai. (2018). The Leadership of the Head Madrasah Based Quality. Nadwa: Jurnal Pendidikan Islam. Vol.12 (1). Pg.15-26.

Yuliana dkk. (2015). Kepemimpinan Kepala Sekolah Dalam Meningkatkan Profesionalisme Guru di SMA Negeri 1 Mempawah Hilir. Pontianak: Media Publikasi. 